\title{
Assessment of Nutrient Deficiencies in Rice (Oryza sativa) through Nutrient Omission in Vertisol and Inceptisol of Chhattisgarh
}

\author{
S.P. Singh ${ }^{2}$, Parmanand ${ }^{1}$, Manisha Choudhary ${ }^{2}$, Chanchala Rani Patel ${ }^{2}$, \\ K.K. Paikra ${ }^{2}$ and Y.K. Sharma ${ }^{3}$ \\ ${ }^{1}$ Department of Soil Science and Agricultural Chemistry, Indra Gandhi Krishi \\ Vishwavidyalaya, Raipur (C.G.), India \\ ${ }^{2}$ Krishi Vigyan Kendra, Raigarh (C.G.) \\ ${ }^{3}$ Department of Agricultural Chemistry and Soil Science, SASRD, Nagaland University, \\ Medziphema, Nagaland, India \\ *Corresponding author
}

\section{Keywords}

Rice, nutrient omission, yield, nutrient uptake, Vertisol, Inceptisol

Article Info

Accepted:

26 June 2018

Available Online:

10 July 2018

\section{A B S T R A C T}

Two pot experiment was conducted at Instructional Farm of Krishi Vigyan Kendra, Raigarh (C.G.) during Kharif season, 2015 for identification of yield limiting nutrients through crop response in Vertisol and Inceptisol of Raigarh district of Chhattisgarh with rice (MTU-1010) as test crop. The experiments were laid out in Completely Randomized Design with 11 treatments and 3 replications. Yield attributing characters viz. effective tillers, filled grains panicle ${ }^{-1}$ and grain and straw yields of rice in both soil types were significantly influenced by nutrient omission treatments. In Vertisol omission of N, P, S and $\mathrm{Zn}$ resulted in significant reductions in yield attributing parameters and grain and straw yields. Highest grain and straw yields (28.69 and $31.35 \mathrm{~g} \mathrm{pot}^{-1}$, respectively) were recorded with the treatment receiving all the nutrients whereas the lowest with omission of $\mathrm{N}$ (18.46 and $21.01 \mathrm{~g} \mathrm{pot}^{-1}$, respectively) followed by $\mathrm{P}, \mathrm{S}$ and $\mathrm{Zn}$ omission. Omission of $\mathrm{N}$ reduced the grain yield by $35.65 \%$ while $\mathrm{P}$ omission reduced grain yield by $28.89 \%$ over the treatment receiving all nutrients. Per cent reduction of grain yield under different nutrient omitted pots followed the order $\mathrm{N}>\mathrm{P}>\mathrm{S}>\mathrm{Zn}$. In Inceptisol, omission of $\mathrm{N}, \mathrm{P}$ and $\mathrm{S}$ reduced the yield attributing parameters and grain and straw yields significantly over the treatment receiving all the nutrients (grain and straw yield being 30.57 and $32.58 \mathrm{~g} \mathrm{pot}^{-1}$, respectively). Omission of $\mathrm{N}, \mathrm{P}$ and $\mathrm{S}$ reduced the grain yield by $47.64 \%, 40.82 \%$ and $19.51 \%$, respectively. Nutrient uptake by rice was significantly reduced with omission of N, P, S and Zn in Vertisol and with omission of N, $\mathrm{P}$ and $\mathrm{S}$ in Inceptisol. On the basis of per cent grain yield reduction, the limiting nutrients found in the order of $\mathrm{N}>\mathrm{P}>\mathrm{S}>\mathrm{Zn}$ in Vertisol and $\mathrm{N}>\mathrm{P}>\mathrm{S}$ in Inceptisol.

\section{Introduction}

Increasing crop production is imperative to meet the growing demand of the population in terms of food, fodder, fiber, fuel, timber and industrial raw material. A continuous increase in yield performance has been achieved through progress in breeding and 
improvements in crop management systems. Fertilizer use has been the key element of this remarkable situation including the high yielding genotypes to realize the potential yield. Presently there is either a plateau or decline in the productivity of many crops across the country, despite earlier steady increase in productivity.

The stagnation in crop productivity has been found due to deficiency of some micro and secondary nutrients (Sakal, 2001). Use of high analysis NPK fertilizers, free from micronutrients, limited use of organic manures and restricted recycling of crop residues are some important factors have contributed towards accelerated exhaustion of secondary and micronutrients from soil. At several places, normal yield of crops could not be achieved despite balanced use of NPK due to micronutrient deficiency in the soils.

Chhattisgarh state has four major soils types i.e. Entisols, Inceptisols, Alfisols and Vertisols. Almost all soils are deficient in nitrogen and phosphorus and medium to high in potassium. In view of continuous use of sulphur free complex fertilizers, chance of increase in sulphur deficiency is likely. Zinc deficiency is commonly observed in Vertisols. Other micronutrients like $\mathrm{Fe}, \mathrm{Mn}, \mathrm{Cu}, \mathrm{B}$ and $\mathrm{Mo}$ may be sufficient for low to medium level of crop production but may not be sufficient for high level of crop production.

High crop yields can only be achieved when crop are properly nutritioned in a correct amount and proper ratios. Ignorance of nutrients other than $\mathrm{N}, \mathrm{P}$ and $\mathrm{K}$ may also limit crop production. Keeping these aspects in view, the present study was undertaken to assessment of nutrient deficiencies in rice through nutrient omission to achieving attainable yield in Vertisols and Inceptisols of Chhattisgarh.

\section{Materials and Methods}

The pot experiments were conducted on rice (MTU-1010) during Kharif, 2015 at the Instructional Farm of Krishi Vigyan Kendra, Raigarh (C.G.). The experimental site is located on the Northern part of Chhattisgarh and lies at $21^{\circ} 54^{\prime} \mathrm{N}$ latitude and $83^{\circ} 24^{\prime} \mathrm{E}$ longitude with an altitude of $215 \mathrm{~m}$ above the mean sea level (MSL). Characteristics of the soils (Vertisol and Inceptisol) are presented in Table 1. The experiments were laid out in completely randomized design with three replications. The treatments for Vertisol were $\mathrm{T}_{1}$ All (N, P, K, S, Fe, Mn, Cu, Zn, B, Mo), T 2 All $-\mathrm{N}, \mathrm{T}_{3}$ All $-\mathrm{P}, \mathrm{T}_{4}$ All $-\mathrm{K}, \mathrm{T}_{5}$ All $-\mathrm{S}, \mathrm{T}_{6}$ All $-\mathrm{Fe}, \mathrm{T}_{7}$ All $-\mathrm{Mn}, \mathrm{T}_{8}$ All $-\mathrm{Cu}, \mathrm{T}_{9}$ All $\mathrm{Zn}, \mathrm{T}_{10}$ All $-\mathrm{B}$, and $\mathrm{T}_{11}$ All $-\mathrm{Mo}$, while for Inceptisol were $\mathrm{T}_{1}$ All $(\mathrm{N}, \mathrm{P}, \mathrm{K}, \mathrm{S}, \mathrm{Ca}, \mathrm{Mg}$, $\mathrm{Cu}, \mathrm{Zn}, \mathrm{B}, \mathrm{Mo}$ ), $\mathrm{T}_{2}$ All $-\mathrm{N}, \mathrm{T}_{3}$ All $-\mathrm{P}, \mathrm{T}_{4}$ All $-\mathrm{K}, \mathrm{T}_{5}$ All $-\mathrm{S}, \mathrm{T}_{6}$ All $-\mathrm{Ca}, \mathrm{T}_{7}$ All $-\mathrm{Mg}, \mathrm{T}_{8}$ All $-\mathrm{Cu}, \mathrm{T}_{9}$ All $-\mathrm{Zn}, \mathrm{T}_{10}$ All $-\mathrm{B}$ and $\mathrm{T}_{11}$ All - Mo (Table 2). Twenty one days old seedlings of rice (MTU-1010) were transplanted on $6^{\text {th }}$ July, 2015 and the pots were maintained with $3 \mathrm{~cm}$ standing water during the crop growing period. The crop was harvested on $9^{\text {th }}$ October, 2015. At harvest yield data of grain and stover of rice was recorded. Nitrogen content was estimated by micro-kjeldahl method (Jackson, 1973). Phosphorus and potassium contents in triacid $\left(\mathrm{HNO}_{3}, \mathrm{HClO}_{4}\right.$ and $\mathrm{H}_{2} \mathrm{SO}_{4}$ in 10:4:1 ratio) were determined by vanadomolybdate yellow colour and flame photometer methods. Sulphur, calcium, magnesium, zinc, iron, copper and boron were determined in diacid $\left(\mathrm{HNO}_{3}\right.$ and $\mathrm{HClO}_{4}$ in 10:4 ratio) by turbidimetric (Chesnin and Yien, 1951), versenate (Chang and Bray, 1951), atomic absorption spectrophotometer and azomethine-H (Gupta,1967) methods. Nutrient uptake was calculated by multiplying grain and straw yields with their respective nutrient contents. 


\section{Results and Discussion}

\section{Yield attributes}

The effective tillers pot $^{-1}$ varied from 8 to 11 in Vertisol and 9 to 12 in Inceptisol (Table 3). The filled grains panicle ${ }^{-1}$ varied from 92.67 to 99.33 and 96.33 to 103.67 in Vertisol and Inceptisol, respectively. Test weight varied from 22.55 to $24.04 \mathrm{~g}$ in Vertisol and from 22.93 to $24.09 \mathrm{~g}$ in Inceptisol. Omission of nitrogen, phosphorus, sulphur and zinc significantly reduced the effective tillers pot $^{-1}$ and grains panicle ${ }^{-1}$ in Vertisol and omission of $\mathrm{N}, \mathrm{P}$ and $\mathrm{S}$ in Inceptisol. Significantly highest number of effective tillers (11 in Vertisol, 12 in Inceptisol) and grains panicle ${ }^{-1}$ (99.33 in Vertisol, 103.67 in Inceptisol) were observed in the treatment receiving all the nutrients $\left(\mathrm{T}_{1}\right)$ and lowest in $\mathrm{N}$ omitted pots followed by omission of $\mathrm{P}, \mathrm{S}$ and $\mathrm{Zn}$. Test weight of rice grain not affected by nutrient omission. Higher yield attributes of rice due to application of all nutrients is attributed to improvement in growth which in turn translocation of photosynthates and nutrients in the reproductive parts resulted more yield attributes (Singh, 2018).

\section{Yield}

Irrespective of soil type and treatments, the grain and stover yields of rice varied from 16.01 to $30.57 \mathrm{~g} \mathrm{pot}^{-1}$ and 18.01 to $32.58 \mathrm{~g}$ pot $^{-1}$, respectively. Highest grain yield (28.69 $\mathrm{g} \mathrm{pot}^{-1}$ ) in Vertisol was recorded in the treatment receiving all the nutrients $\left(\mathrm{T}_{1}\right)$ and lowest grain yield $\left(18.46 \mathrm{~g} \mathrm{pot}^{-1}\right)$ was associated with omission of $\mathrm{N}$. Grain yields with omission of $\mathrm{P}, \mathrm{S}$ and $\mathrm{Zn}$ were 20.40, 24.52 and $25.06 \mathrm{~g} \mathrm{pot}^{-1}$, respectively and were significantly lower than the treatment receiving all the nutrients. Omission of $\mathrm{N}$ reduced the yield by $35.65 \%, \mathrm{P}$ by $28.89 \%, \mathrm{~S}$ by $14.54 \%$ and $\mathrm{Zn}$ by $12.63 \%$ in Vertisol. Highest straw yield $\left(31.35 \mathrm{~g} \mathrm{pot}^{-1}\right)$ of rice was recorded in $T_{1}$ where all the nutrients were applied and lowest $\left(21.01 \mathrm{~g} \mathrm{pot}^{-1}\right)$ in $\mathrm{T}_{2}$ where $\mathrm{N}$ was omitted. Omission of $\mathrm{N}, \mathrm{P}, \mathrm{S}$ and $\mathrm{Zn}$ resulted in significantly lower straw yields in Vertisol. Omission of N, P and S significantly reduced rice grain yield over the treatment receiving all the nutrients in Inceptisol. Highest grain yield $\left(30.57 \mathrm{~g} \mathrm{pot}^{-1}\right)$ was recorded in the treatment receiving all the nutrients $\left(\mathrm{T}_{1}\right)$. Rice grain yields with omission of $\mathrm{N}, \mathrm{P}$ and $\mathrm{S}$ were $16.01,18.09$ and $24.61 \mathrm{~g}$ $\operatorname{pot}^{-1}$, respectively and were significantly lower over treatment receiving all the nutrients $\left(\mathrm{T}_{1}\right)$. Omission of $\mathrm{N}$ reduced grain yield by $47.64 \%$ while $\mathrm{P}$ and $\mathrm{S}$ reduced the yield to the extent of $40.82 \%$ and $19.51 \%$, respectively in Inceptisol. Omission of $\mathrm{N}, \mathrm{P}$ and $\mathrm{S}$ caused significant reductions in straw yields of rice in comparison to the treatment receiving all the nutrients $\left(\mathrm{T}_{1}\right)$. The highest straw yield $(32.58$ $\mathrm{g}$ pot $^{-1}$ ) was recorded in the treatment receiving all the nutrients $\left(T_{1}\right)$. Similar trends in grain and straw yield of rice have also been reported by Mishra et al., (2007).

The grain and straw yield reductions were observed more with $\mathrm{N}$ and $\mathrm{P}$ omission followed by $\mathrm{S}$ and $\mathrm{Zn}$ omission in both soil types. This indicates that $\mathrm{N}$ was the most yield limiting nutrients in both type of the soils followed by P. Under tropical climatic conditions, oxidation loss of organic matter results in low organic carbon and ultimately in available nitrogen causing much reduction in yields (Singh et al., 2000). The soils are low to medium in available $\mathrm{P}, \mathrm{S}$ and $\mathrm{Zn}$ and hence the omission of these nutrients caused significant reduction in yield.

\section{Nutrient uptake}

Total uptake of nutrients by rice was highest in $T_{1}$ treatment which received all nutrients and generally lowest was recorded in $\mathrm{N}$ omitted pots for both types of soils (Table 4 and 5). 
Table.1 Characteristic of experimental soils

\begin{tabular}{|c|c|c|c|}
\hline \multirow[t]{2}{*}{ S. No. } & \multirow[t]{2}{*}{ Characteristics } & \multicolumn{2}{|c|}{ Value } \\
\hline & & Vertisol & Inceptisol \\
\hline 1 & $\mathrm{pH}$ & 7.15 & 6.81 \\
\hline 2 & $\mathrm{EC}\left(\mathrm{dSm}^{-1}\right)$ & 0.29 & 0.12 \\
\hline 3 & Organic carbon $\left(\mathrm{g} \mathrm{kg}^{-1}\right)$ & 4.8 & 5.3 \\
\hline 4 & $\operatorname{CEC}\left(\operatorname{cmol}(p+) \mathrm{kg}^{-1}\right)$ & 34.3 & 18.6 \\
\hline 5 & Available $\mathrm{N}\left(\mathrm{kg} \mathrm{ha}^{-1}\right)$ & 205 & 235 \\
\hline 6 & Available $\mathrm{P}\left(\mathrm{kg} \mathrm{ha}^{-1}\right)$ & 12.5 & 14.2 \\
\hline 7 & Available $\mathrm{K}\left(\mathrm{kg} \mathrm{ha}^{-1}\right)$ & 452 & 337 \\
\hline 8 & Available $\mathrm{S}\left(\mathrm{kg} \mathrm{h}^{-1}\right)$ & 20.1 & 22.3 \\
\hline 9 & Available $\mathrm{Ca}\left(\mathrm{kg} \mathrm{ha}^{-1}\right)$ & 3865 & 1848 \\
\hline 10 & Available $\mathrm{Mg}\left(\mathrm{kg} \mathrm{ha}^{-1}\right)$ & 1023 & 856 \\
\hline 11 & Available Fe $\left(\mathrm{mg} \mathrm{kg}^{-1}\right)$ & 18.58 & 28.35 \\
\hline 12 & Available $\mathrm{Mn}\left(\mathrm{mg} \mathrm{kg}^{-1}\right)$ & 11.35 & 19.52 \\
\hline 13 & Available $\mathrm{Cu}\left(\mathrm{mg} \mathrm{kg}^{-1}\right)$ & 0.76 & 2.01 \\
\hline 14 & Available $\mathrm{Zn}\left(\mathrm{mg} \mathrm{kg}^{-1}\right)$ & 0.87 & 1.41 \\
\hline 15 & Available B $\left(\mathrm{mg} \mathrm{kg}^{-1}\right)$ & 0.48 & 0.53 \\
\hline
\end{tabular}

Table.2 Source and rates of nutrient used in nutrient omission trial

\begin{tabular}{|c|c|c|c|}
\hline Nutrient & $\begin{array}{c}\text { Rate } \\
\left(\mathrm{kg} \mathrm{ha}^{-1}\right)\end{array}$ & Source & Remark \\
\hline $\mathbf{N}$ & 150 & 'Urea & ${ }^{1}$ Added after adjusting the amount added through DAP \\
\hline $\mathbf{P}$ & 100 & ${ }^{2} \mathrm{KH}_{2} \mathrm{PO}_{4} / \mathrm{DAP}$ & ${ }^{2}$ Used in $\mathrm{N}$ omission treatment, \\
\hline $\mathbf{K}$ & 80 & $* \mathrm{MOP}$ & $\begin{array}{l}\text { *Added after adjusting the amount added through } \mathrm{KH}_{2} \mathrm{PO}_{4} \text { in } \mathrm{N} \\
\text { omission treatment, }\end{array}$ \\
\hline $\mathbf{S}$ & 45 & Bentonite S & $\begin{array}{l}{ }^{3} \text { Added after adjusting the amount added through, } \mathrm{FeSO}_{4} 7 \mathrm{H}_{2} \mathrm{O} \text {, } \\
\mathrm{MnSO}_{4} \mathrm{H}_{2} \mathrm{O}, \mathrm{CuSO}_{4} 5 \mathrm{H}_{2} \mathrm{O} \text { and } \mathrm{ZnSO}_{4} 7 \mathrm{H}_{2} \mathrm{O}\end{array}$ \\
\hline $\mathbf{C a}$ & 110 & ${ }^{4} \mathrm{CaCl}_{2} \cdot 2 \mathrm{H}_{2} \mathrm{O}$ & ${ }^{4}$ Used in $\mathrm{Mg}$ omission treatment \\
\hline Mg & 55 & $\mathrm{MgO}$ & - \\
\hline $\mathbf{F e}$ & 20 & $\begin{array}{l}\mathrm{FeSO}_{4} \cdot 7 \mathrm{H}_{2} \mathrm{O} \\
5 \mathrm{FeCl}_{2}\end{array}$ & ${ }^{5}$ Used in S omission treatment \\
\hline Mn & 15 & $\begin{array}{l}\mathrm{MnSO}_{4} \cdot \mathrm{H}_{2} \mathrm{O} \\
{ }^{6} \mathrm{MnCl}_{2}\end{array}$ & ${ }^{6}$ Used in $\mathrm{S}$ omission treatment \\
\hline $\mathbf{C u}$ & 7.5 & $\begin{array}{l}\mathrm{CuSO}_{4} \cdot 5 \mathrm{H}_{2} \mathrm{O} \\
{ }^{7} \mathrm{CuCl}_{2} \cdot 2 \mathrm{H}_{2} \mathrm{O}\end{array}$ & ${ }^{7}$ Used in S omission treatment \\
\hline $\mathbf{Z n}$ & 7.5 & $\begin{array}{l}\mathrm{ZnSO}_{4} \cdot 7 \mathrm{H}_{2} \mathrm{O} \\
{ }^{8} \mathrm{ZnCl}_{2}\end{array}$ & ${ }^{8}$ Used in $\mathrm{S}$ omission treatment \\
\hline B & 3 & $\mathrm{H}_{3} \mathrm{BO}_{3}$ & - \\
\hline Mo & 0.75 & $\mathrm{NaMoO}_{4} \cdot 2 \mathrm{H}_{2} \mathrm{O}$ & - \\
\hline
\end{tabular}


Table.3 Effect of nutrient management practice on yield attributes and yields of rice under Vertisol and Inceptisol

\begin{tabular}{|c|c|c|c|c|c|c|c|c|c|c|c|c|c|}
\hline \multicolumn{2}{|c|}{ Treatments } & \multicolumn{2}{|c|}{$\begin{array}{c}\text { Effective } \\
\text { tillers }\end{array}$} & \multicolumn{2}{|c|}{ Grains panicle $^{-1}$} & \multicolumn{2}{|c|}{$\begin{array}{c}\text { Test weight } \\
\text { (g) }\end{array}$} & \multicolumn{2}{|c|}{$\begin{array}{l}\text { Grain yield } \\
\qquad\left(\mathrm{g} \mathrm{pot}^{-1}\right)\end{array}$} & \multicolumn{2}{|c|}{$\%$ reduction over all } & \multicolumn{2}{|c|}{$\begin{array}{c}\text { Straw yield } \\
\left(\text { g pot }^{-1}\right)\end{array}$} \\
\hline Vert & Inc & Vert & Inc & Vert & Inc & Vert & Inc & Vert & Inc & Vert & Inc & Vert & Inc \\
\hline All & All & 11 & 12 & 99.33 & 103.67 & 24.04 & 24.09 & 28.69 & 30.57 & - & - & 31.35 & 32.58 \\
\hline All -N & All - N & 8 & 9 & 92.67 & 96.33 & 22.55 & 22.93 & 18.46 & 16.01 & 35.65 & 47.64 & 21.01 & 18.01 \\
\hline All $-\mathbf{P}$ & All - P & 9 & 10 & 94.33 & 98.33 & 22.63 & 23.49 & 20.40 & 18.09 & 28.89 & 40.82 & 23.69 & 20.00 \\
\hline All -K & All - K & 11 & 11 & 97.41 & 101.94 & 23.06 & 23.68 & 26.72 & 29.77 & 6.87 & 2.62 & 28.32 & 31.25 \\
\hline All -S & All - S & 9 & 10 & 96.67 & 100.25 & 23.63 & 23.76 & 24.52 & 24.61 & 14.54 & 19.51 & 27.28 & 25.62 \\
\hline All -Fe & All - Ca & 11 & 11 & 97.23 & 102.33 & 23.84 & 23.70 & 28.09 & 28.73 & 2.09 & 6.02 & 30.53 & 30.64 \\
\hline All -Mn & All - Mg & 11 & 11 & 97.65 & 102.61 & 23.55 & 23.74 & 27.78 & 28.82 & 3.15 & 5.74 & 29.39 & 29.78 \\
\hline All -Cu & $\mathrm{All}-\mathrm{Cu}$ & 11 & 11 & 97.33 & 102.33 & 23.66 & 23.76 & 27.01 & 28.08 & 5.84 & 8.15 & 29.29 & 30.55 \\
\hline All $-\mathbf{Z n}$ & All - Zn & 10 & 11 & 96.17 & 101.87 & 23.69 & 23.85 & 25.06 & 28.16 & 12.63 & 7.88 & 27.73 & 30.81 \\
\hline All -B & All - B & 11 & 11 & 97.42 & 102.66 & 23.72 & 23.87 & 27.72 & 28.41 & 3.38 & 7.08 & 30.01 & 31.08 \\
\hline All-Mo & All - Mo & 11 & 12 & 98.67 & 103.00 & 24.00 & 23.92 & 28.18 & 29.25 & 1.77 & 4.32 & 30.83 & 32.30 \\
\hline SEm \pm & & 0.28 & 0.36 & 0.74 & 0.86 & 0.65 & 0.82 & 1.05 & 1.16 & - & - & 1.02 & 1.00 \\
\hline C.D.at $5 \%$ & & 0.88 & 1.12 & 2.29 & 2.66 & NS & NS & 3.24 & 3.59 & - & - & 3.16 & 3.09 \\
\hline
\end{tabular}

Vert $=$ Vertisol, Inc $=$ Inceptisol

All (Vert) = N, P, K, S, Fe, Mn, Cu, Zn, B, Mo

All $($ Inc) $=\mathrm{N}, \mathrm{P}, \mathrm{K}, \mathrm{S}, \mathrm{Ca}, \mathrm{Mg}, \mathrm{Cu}, \mathrm{Zn}, \mathrm{B}, \mathrm{Mo}$ 
Int.J.Curr.Microbiol.App.Sci (2018) 7(7): 3525-3533

Table.4 Effect of nutrient management practice on macro and secondary nutrients uptake by rice under Vertisol and Inceptisol

\begin{tabular}{|c|c|c|c|c|c|c|c|c|c|c|c|}
\hline \multicolumn{2}{|c|}{ Treatments } & \multicolumn{10}{|c|}{ Nutrient uptake $\left(\mathrm{mg} \mathrm{pot}^{-1}\right)$} \\
\hline & & \multicolumn{2}{|c|}{$\mathrm{N}$} & \multicolumn{2}{|c|}{$\mathrm{P}$} & \multicolumn{2}{|c|}{$\mathrm{K}$} & \multicolumn{2}{|c|}{$\mathrm{S}$} & \multirow{2}{*}{$\begin{array}{l}\mathrm{Ca} \\
\mathrm{Inc}\end{array}$} & \multirow{2}{*}{$\begin{array}{l}\mathrm{Mg} \\
\text { Inc }\end{array}$} \\
\hline Vert & Inc & Vert & Inc & Vert & Inc & Vert & Inc & Vert & Inc & & \\
\hline All & All & 498.8 & 520.3 & 107.1 & 129.9 & 567.3 & 566.0 & 88.4 & 89.7 & 291.7 & 88.9 \\
\hline All -N & All - N & 305.2 & 258.7 & 68.0 & 66.9 & 373.39 & 305.8 & 52.5 & 45.2 & 156.4 & 102.6 \\
\hline All $-\mathbf{P}$ & All - P & 355.4 & 298.2 & 64.5 & 68.9 & 422.7 & 343.1 & 59.7 & 52.5 & 175.9 & 159.4 \\
\hline All -K & All - K & 456.1 & 492.6 & 97.7 & 122.9 & 479.8 & 527.7 & 79.2 & 83.8 & 279.8 & 130.7 \\
\hline All -S & All - S & 432.7 & 398.6 & 89.2 & 100.4 & 491.7 & 442.7 & 63.0 & 64.1 & 224.1 & 157.4 \\
\hline All -Fe & All - Ca & 485.7 & 476.3 & 104.5 & 121.1 & 553.1 & 533.2 & 79.1 & 82.3 & 252.7 & 140.8 \\
\hline All -Mn & All - Mg & 471.2 & 472.2 & 102.6 & 119.6 & 536.4 & 521.6 & 80.4 & 78.8 & 261.0 & 157.1 \\
\hline All -Cu & $\mathrm{All}-\mathrm{Cu}$ & 466.9 & 467.4 & 101.5 & 118.9 & 530.3 & 527.2 & 79.8 & 82.2 & 273.3 & 157.5 \\
\hline All -Zn & All - Zn & 424.5 & 467.5 & 89.1 & 120.7 & 494.6 & 528.0 & 70.2 & 81.5 & 271.4 & 159.6 \\
\hline All -B & All - B & 477.6 & 472.5 & 104.6 & 122.7 & 564.2 & 535.5 & 82.9 & 81.3 & 276.5 & 167.8 \\
\hline All -Mo & All - Mo & 481.1 & 495.0 & 108.2 & 125.7 & 557.6 & 557.2 & 84.3 & 85.0 & 287.8 & 88.9 \\
\hline SEm \pm & & 16.7 & 17.6 & 5.8 & 3.9 & 17.6 & 16.9 & 3.0 & 2.8 & 9.4 & 4.7 \\
\hline C.D.at $5 \%$ & & 45.2 & 54.5 & 10.4 & 12.2 & 49.1 & 52.4 & 10.5 & 8.9 & 29.4 & 14.5 \\
\hline
\end{tabular}

Vert $=$ Vertisol, Inc $=$ Inceptisol

All $($ Vert $)=$ N, P, K, S, Fe, Mn, Cu, Zn, B, Mo

All $(\mathrm{Inc})=\mathrm{N}, \mathrm{P}, \mathrm{K}, \mathrm{S}, \mathrm{Ca}, \mathrm{Mg}, \mathrm{Cu}, \mathrm{Zn}, \mathrm{B}, \mathrm{Mo}$ 
Int.J.Curr.Microbiol.App.Sci (2018) 7(7): 3525-3533

Table.5 Effect of nutrient management practice on micronutrients uptake by rice under Vertisol and Inceptisol

\begin{tabular}{|c|c|c|c|c|c|c|c|c|c|}
\hline \multirow{2}{*}{\multicolumn{2}{|c|}{ Treatments }} & \multicolumn{8}{|c|}{ Nutrient uptake $\left(\mathrm{mg} \mathrm{pot}^{-1}\right)$} \\
\hline & & \multicolumn{2}{|c|}{$\mathrm{Zn}$} & \multicolumn{2}{|c|}{$\mathrm{Cu}$} & \multicolumn{2}{|c|}{ B } & \multirow{2}{*}{$\begin{array}{l}\text { Fe } \\
\text { Vert }\end{array}$} & \multirow{2}{*}{$\begin{array}{l}\text { Mn } \\
\text { Vert }\end{array}$} \\
\hline Vert & Inc & Vert & Inc & Vert & Inc & Vert & Inc & & \\
\hline All & All & 1.85 & 2.12 & 0.35 & 0.37 & 0.53 & 0.63 & 8.12 & 11.45 \\
\hline All -N & All - N & 1.16 & 1.07 & 0.23 & 0.20 & 0.32 & 0.31 & 5.35 & 7.51 \\
\hline All -P & All - P & 1.29 & 1.21 & 0.26 & 0.23 & 0.35 & 0.32 & 6.02 & 8.56 \\
\hline All $-K$ & All - K & 1.63 & 1.95 & 0.32 & 0.36 & 0.47 & 0.57 & 7.36 & 10.34 \\
\hline All -S & All - S & 1.46 & 1.49 & 0.30 & 0.30 & 0.40 & 0.44 & 7.05 & 9.82 \\
\hline All-Fe & All - Ca & 1.73 & 1.87 & 0.34 & 0.35 & 0.49 & 0.57 & 7.56 & 10.99 \\
\hline All -Mn & All - Mg & 1.71 & 1.85 & 0.33 & 0.34 & 0.48 & 0.56 & 7.60 & 10.42 \\
\hline All -Cu & All $-\mathrm{Cu}$ & 1.68 & 1.83 & 0.32 & 0.33 & 0.48 & 0.56 & 7.50 & 10.66 \\
\hline All $-\mathbf{Z n}$ & All $-\mathrm{Zn}$ & 1.39 & 1.66 & 0.31 & 0.34 & 0.45 & 0.56 & 7.06 & 10.05 \\
\hline All -B & All - B & 1.77 & 1.89 & 0.35 & 0.35 & 0.42 & 0.47 & 8.08 & 11.38 \\
\hline All -Mo & All - Mo & 1.79 & 2.03 & 0.34 & 0.36 & 0.49 & 0.59 & 8.56 & 11.19 \\
\hline SEm \pm & & 0.06 & 0.07 & 0.01 & 0.01 & 0.02 & 0.03 & 0.04 & 0.52 \\
\hline C.D.at 5\% & & 0.2 & 0.23 & 0.03 & 0.04 & 0.07 & 0.09 & 0.89 & 1.24 \\
\hline
\end{tabular}


Nitrogen uptake by rice under Vertisol and Inceptisol ranged from 305.2 to $498.8 \mathrm{mg}$ pot $^{-}$ ${ }^{1}$ and 258.7 to $520.2 \mathrm{mg} \mathrm{pot}^{-1}$, respectively. Total $\mathrm{N}$ uptake was found maximum in the treatment where all the nutrients were applied $\left(\mathrm{T}_{1}\right)$ and minimum with $\mathrm{N}$ omission pots with a significant difference in both type of soils. Uptake of $\mathrm{N}$ with omission of $\mathrm{P}, \mathrm{S}$ and $\mathrm{Zn}$ was significantly lower than uptake under $T_{1}$ treatment. Total $\mathrm{P}$ uptake was found lowest (64.5 and $66.9 \mathrm{mg} \mathrm{pot}^{-1}$ ) in $\mathrm{P}$ omitted pots in case of Vertisol and in $\mathrm{N}$ omitted pots in case of Inceptisol. Highest P uptake was associated with the treatment receiving all the nutrients closely followed by omission of Mo, B, Fe, $\mathrm{Mn}, \mathrm{Cu}, \mathrm{Ca}, \mathrm{Mg}$ and $\mathrm{K}$ with an insignificant difference to treatment $\mathrm{T}_{1}$. Total $\mathrm{K}$ uptake by rice was found maximum in the treatment where all the nutrients were applied $\left(\mathrm{T}_{1}\right)$. K uptake in N, P, K, S and Zn omitted pots were significantly lower than $T_{1}$ treatment in case of Vertisol. In case of Inceptisol, omission of $\mathrm{N}, \mathrm{P}$ and $\mathrm{S}$ reduced $\mathrm{K}$ uptake significantly in comparison to $\mathrm{T}_{1}$ treatment. However, omission of other nutrients could not affect $\mathrm{K}$ uptake significantly over $\mathrm{T}_{1}$ treatment. Total $\mathrm{S}$ uptake was found maximum in the treatment where all the nutrients were applied $\left(\mathrm{T}_{1}\right)$ and minimum in the treatment where $\mathrm{N}$ was omitted in case of both type of soils. Irrespective of treatments and soils type, the $\mathrm{S}$ uptake was ranged from 45.24 to $89.74 \mathrm{mg}$ $\operatorname{pot}^{-1}$. Omission of $\mathrm{N}, \mathrm{P}$ and $\mathrm{S}$ significantly reduced $S$ uptake by rice over $T_{1}$ treatment in case of both type of soils. Zinc omission in Vertisol and $\mathrm{Mg}$ omission in Inceptisol reduced $\mathrm{S}$ uptake significantly over $\mathrm{T}_{1}$ treatment. Total uptake of $\mathrm{Ca}$ was found maximum (291.7 $\mathrm{mg} \mathrm{pot}^{-1}$ ) in the treatment where all the nutrients were applied $\left(\mathrm{T}_{1}\right)$ and minimum (156.4 $\mathrm{mg} \mathrm{pot}^{-1}$ ) in $\mathrm{N}$ omitted pots. Uptake of $\mathrm{Ca}$ with omission of $\mathrm{N}, \mathrm{P}, \mathrm{S}, \mathrm{Ca}$ and $\mathrm{Mg}$ declined significantly as compared to treatment $\mathrm{T}_{1}$. Maximum $\mathrm{Mg}$ uptake $(170.7 \mathrm{mg}$ $\operatorname{pot}^{-1}$ ) was recorded in treatment $T_{1}$ and minimum ( $\left.88.9 \mathrm{mg} \mathrm{pot}^{-1}\right)$ in the $\mathrm{N}$ omitted treatment and difference was significant. The uptake of $\mathrm{Mg}$ with omission of $\mathrm{P}, \mathrm{S}$ and $\mathrm{Mg}$ were significantly lower than the uptake observed with $\mathrm{T}_{1}$ in Inceptisol. Maximum $\mathrm{Zn}$ uptake was found in the treatment receiving all the nutrients $\left(\mathrm{T}_{1}\right)$ and minimum in $\mathrm{N}$ omitted pots and the difference was significant. Significantly lower Zn uptake was observed with omission of $\mathrm{P}, \mathrm{S}$ and $\mathrm{Zn}$ in Vertisol. Significantly lower Zn uptake was also observed with omission of $\mathrm{P}, \mathrm{S}, \mathrm{Zn}, \mathrm{Cu}$ and $\mathrm{Mg}$ in Inceptisol. Omission of $\mathrm{N}, \mathrm{P}, \mathrm{S}$ and $\mathrm{Zn}$ reduced the total $\mathrm{Cu}$ uptake significantly in Vertsol. Highest $\mathrm{Cu}$ uptake $(0.35 \mathrm{mg} / \mathrm{pot})$ was associated with treatment $T_{1}$. The uptake of $\mathrm{Cu}$ with omission of $\mathrm{N}, \mathrm{P}, \mathrm{S}$ and $\mathrm{Zn}$ was remarkably lower than uptake by $\mathrm{T}_{1}$ in Vertisol. Omission of $\mathrm{N}, \mathrm{P}$ and $\mathrm{S}$ caused significant reductions in $\mathrm{Cu}$ uptake by rice in Inceptisol. Total uptake of B was found highest in $\mathrm{T}_{1}$ treatment. Significantly lower B uptake was associated with omission of $\mathrm{N}, \mathrm{P}$, $\mathrm{S}, \mathrm{B}$, and $\mathrm{Zn}$ in Vertisol. Uptake of $\mathrm{B}$ with omission of $\mathrm{N}, \mathrm{P}, \mathrm{S}$ and $\mathrm{B}$ reduced significantly than uptake with $\mathrm{T}_{1}$ in Inceptisol. Omission of $\mathrm{N}, \mathrm{P}, \mathrm{S}$ and $\mathrm{Zn}$ significantly reduced the total $\mathrm{Fe}$ uptake by rice in comparison to the treatment receiving all the nutrients $\left(\mathrm{T}_{1}\right)$ in Vertisol. Maximum total $\mathrm{Fe}$ uptake $\left(8.12 \mathrm{mg}^{-1}\right)$ recorded in $\mathrm{T}_{1}$ treatment and minimum (5.35 mg pot $\left.{ }^{-1}\right)$ in $\mathrm{N}$ omitted pots and the difference was significant. The uptake of Fe with omission of $\mathrm{P}, \mathrm{S}$ and $\mathrm{Zn}$ reduced remarkably over $\mathrm{T}_{1}$. Omission of N, P and $\mathrm{S}$ significantly reduced Mn uptake in Vertisol and the reduction was more pronounced with $\mathrm{N}$ omission. Maximum Mn uptake (11.45 mg pot $\left.^{-1}\right)$ was recorded in $\mathrm{T}_{1}$ treatment and minimum $\left(7.51 \mathrm{mg} \mathrm{pot}^{-1}\right)$ in the treatment where $\mathrm{N}$ was omitted. $\mathrm{Mn}$ uptake with omission of $\mathrm{P}, \mathrm{S}$ and $\mathrm{Zn}$ was significantly lower than uptake by $T_{1}$. Application of all nutrients ( $T_{1}$ treatment) increased the grain and straw yields as well as the nutrient concentrations resulted more uptake of nutrients. Generally significantly 
lower nutrients uptake by rice was observed with nitrogen, phosphorus, sulphur and zinc omission because of low grain and straw yields. These results are in accordance with those of Mishra et al., (2007) and Singh (2016).

From these results, it may be concluded that application of $\mathrm{N}, \mathrm{P}, \mathrm{K}, \mathrm{S}$ and $\mathrm{Zn}$ might be benifecial under Vertisol and Inceptisol of Chhattisgarh state for achieving higher productivity of rice. Nitrogen and phosphorus are most limiting nutrients and their omission caused drastic reduction of yield under both types of soils.

\section{References}

Chang, K.L. and Bray, R.H. (1951) Determination of calcium and magnesium in soil and plant material. Soil Science 72 (6): 449-458.

Chesnin, L. and Yien, C.H. (1951) Turbidimetric determination of available sulphates. Proceedings of Soil Science Society of America 15: 149-151.

Gupta, U.C. (1967) A simplified method for determining hot-water soluble boron in podzol soils. Soil Science 103: 424428.

Jackson, M. L. (1973) Soil Chemical Analysis. Prentice-Hall of India Pvt
Ltd., New Delhi.

Mishra, V.N., Patil, S.K., Das, R.O., Shrivastava, L.K., Samadhiya, V.K. and Sengar, S.S. (2007) Site-specific nutrient management for maximum yield of rice in Vertisol and Inceptisol of Chhattisgarh. Paper presented in South Asian Conference on "Water in Agriculture: management options for increasing crop productivity per drop of water", during November, 15-17, held at IGKV, Raipur C.G., India. P.136

Sakal, R. (2001) Efficient management of micronutrients for sustainable crop production. Journal of the Indian Society of Soil Science 49(4): 593-608.

Singh, V. (2016) Productivity, nutrient uptake and economics of wheat as affected by nutrient omissions in alluvial soils. Annals of Plant and Soil Research 18 (3):219-225.

Singh, V. (2018) Breaking yield barrier in wheat (Triticum aestivum) through site specific nutrient management. Annals of Plant and Soil Research 20 (1):112115.

Singh, R.N., Singh, R.N.P., and Diwakar, D.P.S. (2000) Characterization of old alluvial soils of Sone basin. Journal of the Indian Society of Soil Science 48(2): 352-357.

\section{How to cite this article:}

Singh, S.P., Parmanand, Manisha Choudhary, Chanchala Rani Patel, K.K. Paikra and Sharma, Y.K. 2018. Assessment of Nutrient Deficiencies in Rice (Oryza sativa) through Nutrient Omission in Vertisol and Inceptisol of Chhattisgarh. Int.J.Curr.Microbiol.App.Sci. 7(07): 35253533. doi: https://doi.org/10.20546/ijcmas.2018.707.409 